\title{
Spring water quality assessment using water quality index in villages of Barwari Bala, Duhok, Kurdistan Region, Iraq
}

\author{
Hajar Ameen Ameen ${ }^{1}$ (D)
}

Received: 2 October 2018 / Accepted: 10 October 2019 / Published online: 14 October 2019

(C) The Author(s) 2019

\begin{abstract}
Periodic quality assessment of drinking water sources is necessary to guarantee the quality and security of water supply to people. Accordingly, this study assessed the drinking water quality of spring water of some villages located in Barwari Bala region of Duhok Governorate, Kurdistan region, Iraq, using the water quality index (WQI). To realize this objective, 120 spring water samples were collected from ten villages during the dry and wet seasons in 2018 and were analyzed for major physicochemical characteristics, including: calcium $\left(\mathrm{Ca}^{2+}\right)$, magnesium $\left(\mathrm{Mg}^{2+}\right)$, sodium $\left(\mathrm{Na}^{+}\right)$, potassium $\left(\mathrm{K}^{+}\right)$, chloride $\left(\mathrm{Cl}^{-}\right)$, sulfate $\left(\mathrm{SO}_{4}{ }^{2-}\right)$, nitrate $\left(\mathrm{NO}_{3}{ }^{-}\right)$, $\mathrm{pH}$, total dissolved solids (TDS), turbidity, total hardness (TH) and total alkalinity (TA). The results for $\mathrm{pH}$, turbidity, sodium, potassium, chloride, sulfate and nitrate showed that the water samples at all the sampled springs were suitable for drinking and within permissible limits based on given standards. However, TDS, TA, calcium and magnesium exceeded the permissible limits at some sites. It was also observed that, except for $\mathrm{SO}_{4}{ }^{2-}$, at almost all the sites, the majority of parameters were significantly greater during the wet season compared to the dry season. With reference to all the parameters, the WQI values ranged from 10.76 to 18.13 during the dry season and from 17.10 to 20.45 during the wet season, indicating that all water samples are classified as having "excellent" water quality for drinking purposes. The calculation of WQI based on specific parameters, where values were close to or exceeded the maximum acceptable limits, showed that the water quality status of all water samples was "good" quality, except for sites S6 and S8, which were classified as "poor" quality and are not considered suitable for drinking purposes without treatment. Water from almost all the sampled spring sites can be considered as suitable for drinking purposes, although some parameters exceed permissible limits. Simple filtration treatment of the sampled spring water before use is desirable for ensuring good quality and security of the water supply to people of these areas.
\end{abstract}

Keywords Drinking water $\cdot$ Water quality assessment $\cdot$ Water quality index (WQI) $\cdot$ Spring water $\cdot$ Physicochemical parameters

\section{Introduction}

Water is considered as the most important and valuable natural resource on which all life on earth ultimately depends. Water plays an imperative role in the development of different sectors of the economy, including agriculture, cattle production, forestry, industrial electricity generation, fisheries, and other innovative activities (Bouslah et al. 2017; Tyagi et al. 2013). However, the continuous growth of the human population is increasing the demands for water, and

Hajar Ameen Ameen

Hajar.ameen@uod.ac

1 Department of Soil and Water Science, University of Duhok, Duhok, Kurdistan Region, Iraq the sustainability of the freshwater supply is significantly threatened due to extensive depletion of groundwater, surface water contamination, and the effects of climate change (IPCC 2007; Poudel and Duex 2017). Consequently, numerous countries are facing serious water scarcity and poor water quality. Thus, information on water resources and their suitability for use is mandatory for spatial planning and sustainable development. This is of particular importance in arid and semiarid areas, where water resources are limited and the long-term average precipitation is decreasing (Barakat et al. 2018; Mishra and Singh 2010; Tallaksen and Van Lanen 2004).

Like other countries in arid and semiarid zones, Iraq experiences water shortages and has limited freshwater resources to meet the local population's water needs. In the 
Kurdistan region, the primary sources of water for human activities include groundwater, rivers, dams, ponds, handdug wells, and springs. The quality and quantity of these water sources vary depending on the geographic location and environmental factors, such as the chemical composition of the underlying rocks, precipitation inputs, soil formation, and the length of time that the water body has been trapped underground (Faniran et al. 2001; Van der Merwe 1962). These water bodies may be threatened further as a consequence of human development (Yogendra and Puttaiah 2008). Monitoring and conserving these important water sources is necessary for healthy living and an adequate supply of safe drinking water.

Over the past few decades, the water quality index (WQI) has been considered as an effective tool that provides information on the quality of water for use by concerned citizens and policymakers (Yisa et al. 2012) and has been utilized in surface and groundwater quality evaluation all over the world (Bora and Goswami 2017; Kaviarasan et al. 2016; Samantray et al. 2009). The WQI indicates the quality of water in terms of an index number which represents the overall quality of water in relation to specific standards for specific uses (Etim et al. 2013). WQI is defined as a rating reflecting the overall effect of various water quality parameters. The first WQI was proposed by Horton (1965), and subsequently, there have been improvements to the original technique. Accordingly, numerous WQIs have been formulated and approved around the world (Brown et al. 1970; Ganiyu et al. 2017; Reza and Singh 2010; Shigut et al. 2017), which vary in terms of statistical incorporation and translation of parameter values (Abbasi and Abbasi 2012; Alobaidy et al. 2010).

Springs are the primary source of water for drinking, agricultural, and domestic purposes in most villages in the Kurdistan region. Although spring water is considered inexpensive and of high-quality due to its filtration through the soil layers, the quality of this water source is based on certain physiochemical parameters. In the Kurdistan region, spring water is mainly used for drinking and rural domestic use; hence, it should be tested and compared against domestic water quality standards to ensure safe drinking water. WQIs have been applied worldwide and are used to assess the overall water quality within a particular region quickly and effectively (Abdulwahid 2013). However, in the Kurdistan region of Iraq, few studies have been conducted on spring water using WQIs. In addition, to the best of our knowledge, the spring water quality of many villages in the area was left an assessed. The present study, therefore, evaluates the drinking water quality and present the application of the WQI as a possible tool for monitoring the quality of spring water in villages within the Barwari Bala area at Duhok Governorate, Kurdistan region, Iraq.

\section{Materials and methods}

\section{Study area and sampling sites}

In this study, water samples were collected from the springs in 10 villages within the Barwari Bala area. Barwari Bala is a region situated in the north of Iraq at a distance of about $105 \mathrm{~km}$ from Duhok and $584 \mathrm{~km}$ from Baghdad. The study area lies between the latitude $37^{\circ} 10^{\prime} 02^{\prime \prime} \mathrm{N}$ and $37^{\circ} 16^{\prime} 10^{\prime \prime} \mathrm{N}$ and longitudes $43^{\circ} 10^{\prime} 09^{\prime \prime} \mathrm{E}$ and $43^{\circ} 29^{\prime} 45^{\prime \prime} \mathrm{E}$. The name and geographic coordinates of the investigated springs are presented in Fig. 1 and Table 1. The geography of the area is mountainous, and the climate is considered semiarid, characterized by hot, dry summers and cold, wet winters and is usually snowy with more rainfall in the north than in the central and southern parts. The area receives an annual rainfall of 750-900 $\mathrm{mm}$. The major water sources are springs and rivers, and a great proportion of the population obtains water from springs for drinking and domestic purposes.

\section{Sampling and sample analysis}

A total of 120 water samples were collected from 10 different springs at two different sampling periods. Sampling was undertaken during the wet season (December-April), when the area had received sufficient rainfall to cause runoff, and during the dry season (July-October 2018), when the area had not received rainfall for some months. During each season, six water samples at 10-15-day intervals were collected from each spring. Stopper-fitted polyethylene bottles (capacity $500 \mathrm{~mL}$ ) were used for collecting water samples. Prior to sampling, the bottles were triple-rinsed with distilled water. After sampling, the samples were transported to the Central Laboratory of College of Agriculture, University of Duhok, Kurdistan region, Iraq, and refrigerated at $4{ }^{\circ} \mathrm{C}$ for physicochemical analysis.

The samples were analyzed for $\mathrm{pH}$, total dissolved solids (TDS), turbidity, total hardness, total alkalinity, $\mathrm{Ca}^{2+}$, $\mathrm{Mg}^{2+}, \mathrm{K}^{+}, \mathrm{Na}^{+}, \mathrm{Cl}^{-}, \mathrm{NO}^{3-}$, and $\mathrm{SO}_{4}^{-2}$ in accordance with the procedures delineated in the standard methods described by Motsara and Roy (2008) and APHA (1995). Electrical conductivity (EC) and $\mathrm{pH}$ of each water sample were measured in situ. Table 2 shows the technical and methods used for the analysis of different parameters, along with the instruments and units used in this study.

\section{WQI calculation}

The WQI of all drinking water samples was assessed by applying the weighted arithmetic index method employed by Brown et al. (1972). The WQI is used to determine the 
Fig. 1 Map of Iraq with a satellite image of the study area illustrating the sampling sites

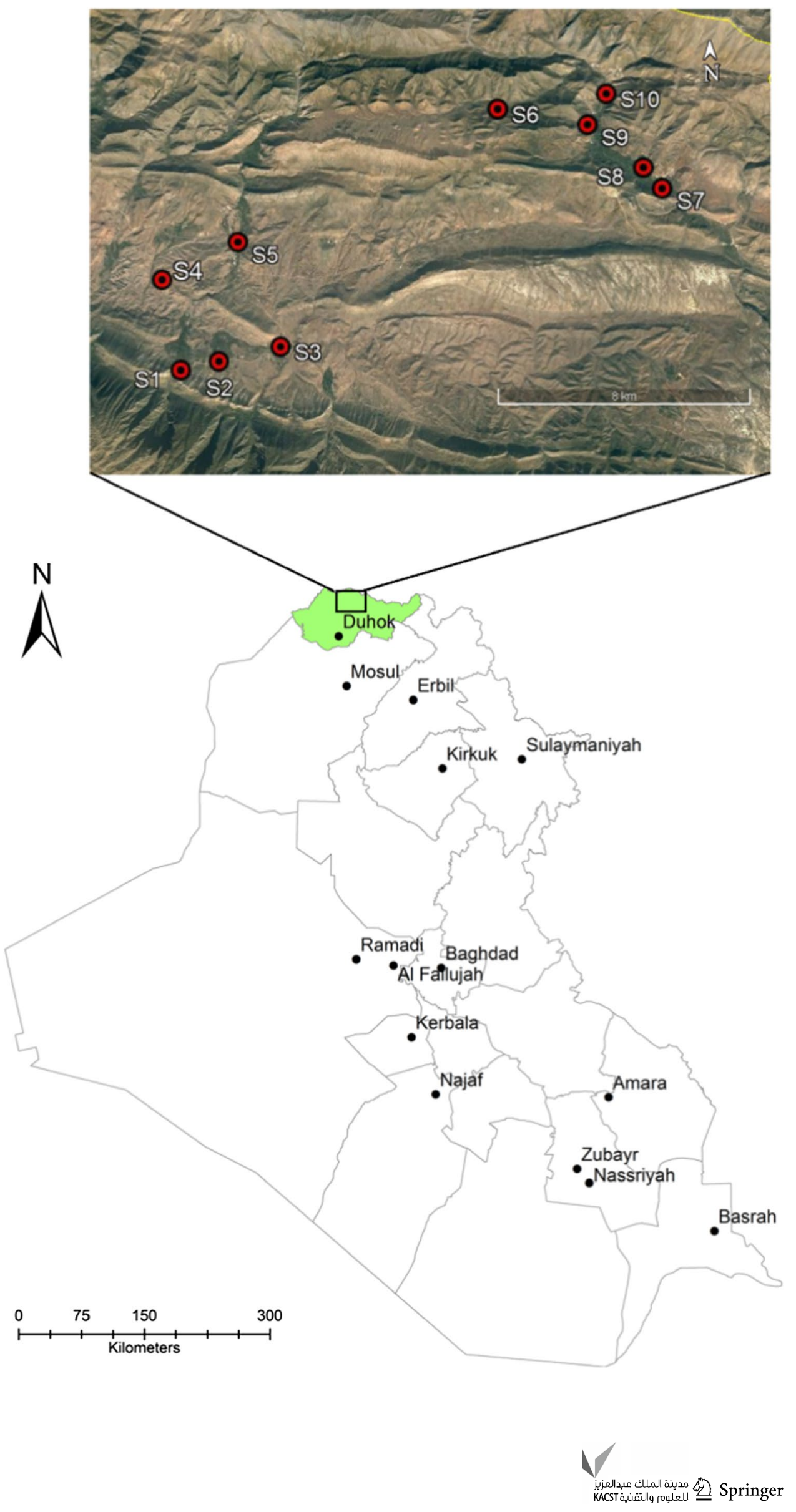


Table 1 The name and geographic coordinates of the sample springs

\begin{tabular}{llll}
\hline Names of sampling sites & $\begin{array}{l}\text { Sampling } \\
\text { site codes }\end{array}$ & Latitude & Longitude \\
\hline Kyle Baze & $\mathrm{S} 1$ & $37^{\circ} 10^{\prime} 31.28^{\prime \prime} \mathrm{N}$ & $43^{\circ} 15^{\prime} 28.76^{\prime \prime} \mathrm{E}$ \\
Kani Mazne & $\mathrm{S} 2$ & $37^{\circ} 10^{\prime} 39.74^{\prime \prime} \mathrm{N}$ & $43^{\circ} 16^{\prime} 26.03^{\prime \prime} \mathrm{E}$ \\
Miska & $\mathrm{S} 3$ & $37^{\circ} 10^{\prime} 54.37^{\prime \prime} \mathrm{N}$ & $43^{\circ} 17^{\prime} 50.87^{\prime \prime} \mathrm{E}$ \\
Xshxasha & $\mathrm{S} 4$ & $37^{\circ} 12^{\prime} 06.5^{\prime \prime} \mathrm{N}$ & $43^{\circ} 15^{\prime} 11.42^{\prime \prime} \mathrm{E}$ \\
Beqolke & $\mathrm{S} 5$ & $37^{\circ} 12^{\prime} 44.15^{\prime \prime} \mathrm{N}$ & $43^{\circ} 16^{\prime} 54.81^{\prime \prime} \mathrm{E}$ \\
Bnavi & $\mathrm{S} 6$ & $37^{\circ} 14^{\prime} 33.58^{\prime \prime} \mathrm{N}$ & $43^{\circ} 22^{\prime} 50.45^{\prime \prime} \mathrm{E}$ \\
Kani Mase & $\mathrm{S} 7$ & $37^{\circ} 13^{\prime} 29.2^{\prime \prime} \mathrm{N}$ & $43^{\circ} 26^{\prime} 18.88^{\prime \prime} \mathrm{E}$ \\
Derishke & $\mathrm{S} 8$ & $37^{\circ} 13^{\prime} 51.59^{\prime \prime} \mathrm{N}$ & $43^{\circ} 25^{\prime} 54.9^{\prime \prime} \mathrm{E}$ \\
Maye & $\mathrm{S} 9$ & $37^{\circ} 14^{\prime} 38.3^{\prime \prime} \mathrm{N}$ & $43^{\circ} 24^{\prime} 40.8^{\prime \prime} \mathrm{E}$ \\
Bedhi & $\mathrm{S} 10$ & $37^{\circ} 15^{\prime} 10.06^{\prime \prime} \mathrm{N}$ & $43^{\circ} 25^{\prime} 08.29^{\prime \prime} \mathrm{E}$ \\
& & &
\end{tabular}

composite effect of individual parameters on the overall quality of water. In essence, twelve important parameters were chosen for the WQI calculation. International standards were used to assess the quality of different water samples (See Table 3). However, where parameters were not set in international standards, other national standards were used. The calculation of WQI involves the following steps:

In the first step, the unit weight $\left(W_{n}\right)$ for each water quality parameter has been calculated using the following formula:

$W_{n}=K / S_{n}$

where $W_{n}$ is the unit weight and $S_{n}$ is the recommended standard for an $i$ th parameter (Table 4), while $\mathrm{k}$ is the constant of proportionality and it was calculated using the following equation:

$K=1 / \Sigma\left(1 / S_{n}\right)$

In the second step, a quality rating score $\left(Q_{n}\right)$ or subindex for all the parameters except $\mathrm{pH}$ was calculated by dividing the concentration of each parameter by its respective standard. The result was then multiplied by 100 as follows:

$Q_{n}=\left[\left(V_{n}-V_{i}\right) /\left(V_{s}-V_{i}\right)\right] \times 100$

where $V_{n}$ is the actual amount of $n$th parameter present, $V_{i}$ is the ideal value of the parameter $\left[V_{i}=0\right.$, except for $\mathrm{pH}\left(V_{i}=7\right)$, $V_{s}$ is the recommended standard or permissible limit for the $n$th water quality parameter.

The above equation indicates that $Q_{n}=0$ when a pollutant is absent from the water sample and $Q_{n}=100$ when the value of this parameter is just equal to its recommended value. Hence, the higher the value of $Q_{n}$, the higher the level of contamination.

Finally, the overall WQI for each sample was calculated using the following equation:

$W Q I=\frac{\sum Q_{n} W_{n}}{\sum W_{n}}$

where $Q_{n}$ referred to the quality rating of $n$th water quality parameter and $W_{n}$ is the unit weight of $n$th water quality parameter.

The computed WQI values were then classified into five categories in order to determine the water quality status (WQS) as shown in Table 5.

\section{Statistical analysis}

Descriptive statistics, such as mean and standard deviation (SD), were calculated to describe the variation of each parameter. Paired $T$ test was performed to determine if there are significant variations (at 95\% confidence level) in the selected parameters between seasons. Prior to analysis, data were evaluated for normal distribution using the Kolmogorov-Smirnov normality test (if $p$ value $<0.05$ data considered non-normal). Long Logarithmic $\left(\log _{10}\right)$ transformation was used where the data were non-normally distributed. All
Table 2 Water quality parameters, analytical methods, and instruments used for the current study

\begin{tabular}{|c|c|c|}
\hline Parameters & Unit & Instruments/analytical methods used \\
\hline $\mathrm{pH}$ & & Digital pH meter (EcoScan pH 5 Palmtop pH meter) \\
\hline Total dissolved solids (TDS) & $\mathrm{mg} / \mathrm{L}$ & Conductivity meter (waterproof conductivity meter HI 9835) \\
\hline Turbidity & NTU & $\begin{array}{l}\text { Digital turbidity meter (HF Scientific 20016, micro } 1000 \text { IR labora- } \\
\text { tory turbidimeter) }\end{array}$ \\
\hline Calcium $\left(\mathrm{Ca}^{+2}\right)$ & $\mathrm{mg} / \mathrm{L}$ & EDTA titrimetric method \\
\hline Magnesium $\left(\mathrm{Mg}^{+2}\right)$ & $\mathrm{mg} / \mathrm{L}$ & EDTA titrimetric method \\
\hline Sodium $\left(\mathrm{Na}^{+}\right)$ & $\mathrm{mg} / \mathrm{L}$ & Flame-photometric method (Jenway PFP7 clinical flame photometer) \\
\hline Potassium $\left(\mathrm{K}^{+}\right)$ & $\mathrm{mg} / \mathrm{L}$ & Flame-photometric method (Jenway PFP7 clinical flame photometer) \\
\hline Chloride $\left(\mathrm{CL}^{-}\right)$ & $\mathrm{mg} / \mathrm{L}$ & $\mathrm{AgNO}_{3}$ titrimetric method \\
\hline Sulfate $\left(\mathrm{SO}_{4}^{-2}\right)$ & $\mathrm{mg} / \mathrm{L}$ & Barium sulfate turbidity (Spectrophotometer) \\
\hline Nitrate $\left(\mathrm{NO}_{3}^{-}\right)$ & $\mathrm{mg} / \mathrm{L}$ & Steam distillation method (Kjeldahl) \\
\hline Total hardness as $\mathrm{CaCO}_{3}$ & $\mathrm{mg} / \mathrm{L}$ & EDTA titrimetric method \\
\hline
\end{tabular}

مدينة الملك عبدالعزيز

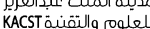


Table 3 National and international standards related to assessing the quality of spring water

\begin{tabular}{|c|c|c|c|c|c|}
\hline \multirow[t]{2}{*}{ Parameter } & \multirow[t]{2}{*}{ Unit } & \multirow{2}{*}{$\begin{array}{l}\text { WHO (2017) } \\
\text { Drinking water }(\mathrm{Gv})^{\mathrm{a}}\end{array}$} & \multirow{2}{*}{$\begin{array}{l}\text { EPA (2018) } \\
\text { Drinking water (MCL) }\end{array}$} & \multirow{2}{*}{$\begin{array}{l}\text { (Drinking Water } \\
\text { Standard IQS:417 } \\
\text { 2001) } \\
(\text { MPL) }\end{array}$} & \multirow{2}{*}{$\begin{array}{l}\text { Turkish Legislation R.G. no. } \\
\text { 23144a (Gazete 1997) } \\
\text { Bottled drinking water (MAC) }\end{array}$} \\
\hline & & & & & \\
\hline $\mathrm{pH}$ & & - & $6.5-8.5^{\mathrm{e}}$ & $6.5-8.5$ & $5.5-8.5$ \\
\hline Turbidity & NTU & - & & $5^{e}$ & 5 \\
\hline TDS & $\mathrm{mg} / \mathrm{L}$ & - & $500^{\mathrm{e}}$ & 1000 & - \\
\hline $\mathrm{Ca}^{2+}$ & $\mathrm{mg} / \mathrm{L}$ & - & - & $75^{\mathrm{e}}$ & 100 \\
\hline $\mathrm{Mg}^{2+}$ & $\mathrm{mg} / \mathrm{L}$ & - & - & $50^{\mathrm{e}}$ & 50 \\
\hline $\mathrm{Cl}^{-}$ & $\mathrm{mg} / \mathrm{L}$ & - & $250^{\mathrm{g}}$ & 250 & 250 \\
\hline $\mathrm{Na}^{+}$ & $\mathrm{mg} / \mathrm{L}$ & - & - & $200^{\mathrm{e}}$ & 175 \\
\hline $\mathrm{K}^{+}$ & $\mathrm{mg} / \mathrm{L}$ & - & - & - & $12^{\mathrm{e}}$ \\
\hline $\mathrm{SO}_{4}^{2-}$ & $\mathrm{mg} / \mathrm{L}$ & - & $250^{\mathrm{e}}$ & 250 & 250 \\
\hline $\mathrm{NO}_{3}^{-}$ & $\mathrm{mg} / \mathrm{L}$ & $50^{\mathrm{e}}$ & 44 & 50 & 45 \\
\hline Total alkalinity $\mathrm{CaCO}_{3}$ & $(\mathrm{mg} / \mathrm{L})$ & - & - & $200^{\mathrm{e}}$ & - \\
\hline Total hardness $\mathrm{CaCO}_{3}$ & $\mathrm{mg} / \mathrm{L}$ & - & - & $500^{\mathrm{e}}$ & - \\
\hline
\end{tabular}

WHO World Health Organization, EPA US Environmental Protection Agency

${ }^{\text {a }}$ Guideline value

${ }^{\mathrm{b}}$ Maximum contaminant level

${ }^{\mathrm{c}}$ Maximum permissible limits

${ }^{\mathrm{d}}$ Maximum admissible concentration

${ }^{\mathrm{e}}$ depended values for comparison and water quality assessment

Table 4 Recommended Standards for drinking water quality and unit weight of individual parameters

\begin{tabular}{llll}
\hline NTU & Parameters & $\begin{array}{l}\text { Recommended } \\
\text { water quality stand- } \\
\text { ards }\left(\mathrm{S}_{\mathrm{n}}\right)\end{array}$ & $\begin{array}{l}\text { Units } \\
\text { weight } \\
\left(W_{n}\right)\end{array}$ \\
\hline $\mathrm{pH}$ & & $6.5-8.5$ & 0.247 \\
Turbidity & $\mathrm{NTU}$ & 5 & 0.420 \\
Total dissolved solid & $(\mathrm{mg} / \mathrm{L})$ & 500 & 0.004 \\
Calcium & $(\mathrm{mg} / \mathrm{L})$ & 75 & 0.028 \\
Magnesium & $(\mathrm{mg} / \mathrm{L})$ & 50 & 0.042 \\
Chloride & $(\mathrm{mg} / \mathrm{L})$ & 250 & 0.008 \\
Sodium & $(\mathrm{mg} / \mathrm{L})$ & 200 & 0.011 \\
Potassium & $(\mathrm{mg} / \mathrm{L})$ & 12 & 0.175 \\
Sulfate & $(\mathrm{mg} / \mathrm{L})$ & 250 & 0.008 \\
Nitrate & $(\mathrm{mg} / \mathrm{L})$ & 50 & 0.042 \\
Total alkalinity & $\mathrm{CaCO}(\mathrm{mg} / \mathrm{L})$ & 200 & 0.011 \\
Total hardness & $\mathrm{CaCO}(\mathrm{mg} / \mathrm{L})$ & 500 & 0.004 \\
& & & 1.001 \\
\hline
\end{tabular}

statistical analyses were conducted using the Minitab software package 17 .

\section{Results and discussion}

The relative abundance of major dissolved chemical constituents in water is dependent upon weathering process, type of geological rock (Singh and Hasnain 1999), and inputs from anthropogenic activities. The physicochemical analysis is used for detecting the levels of these dissolved constituents in water (Barakat et al. 2018). Accordingly, in the current study, the collected samples from spring water in different villages in the Barwari Bala region were analyzed for 12 physicochemical parameters. The summary of the results derived from descriptive statistics [Mean $\pm \mathrm{SD}$ ] for measured variables at 10 sample points during dry and wet seasons and the suggested standards are shown in Tables 6 and 7. In addition, the paired $t$ test analysis results for seasonal variation
Table 5 WQI ranges, status, and possible use of the water sample (Brown et al. 1972)

\begin{tabular}{lll}
\hline WQI & Water quality status & Possible use \\
\hline $0-25$ & Excellent & Drinking, irrigation, and industrial \\
$26-50$ & Good & Drinking, irrigation, and industrial \\
$51-75$ & Poor & Irrigation and industrial \\
$76-100$ & Very poor & Irrigation \\
More than 100 & Unsuitable for drinking & Proper treatment required before use \\
\hline & &
\end{tabular}




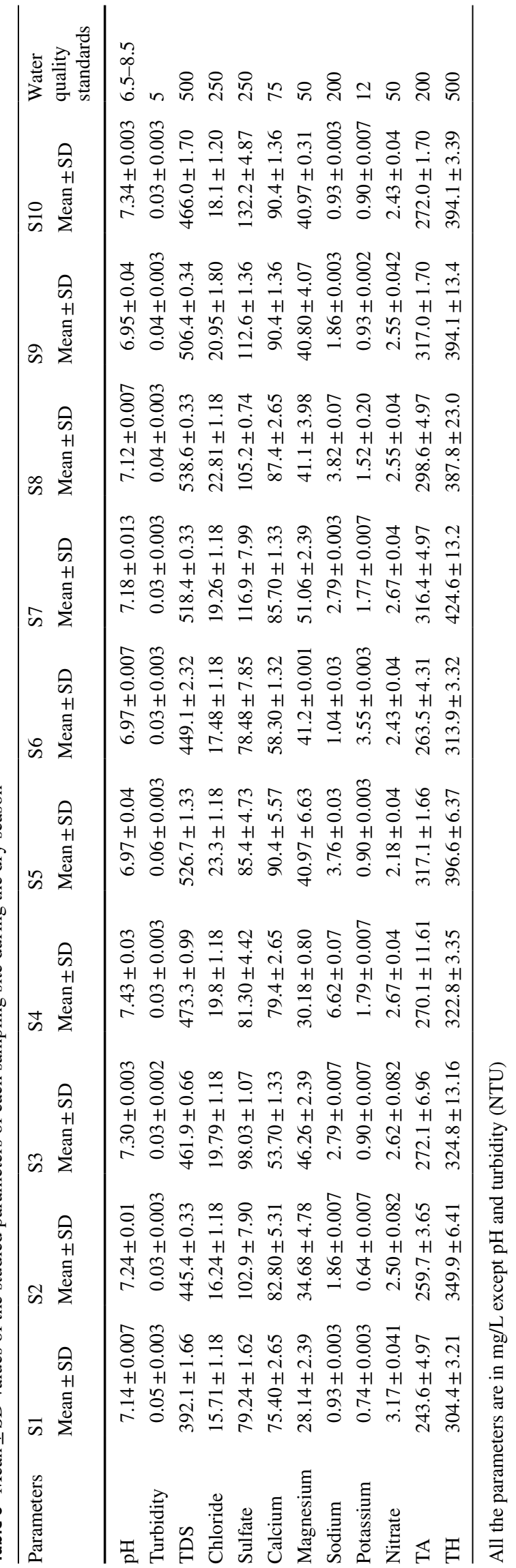

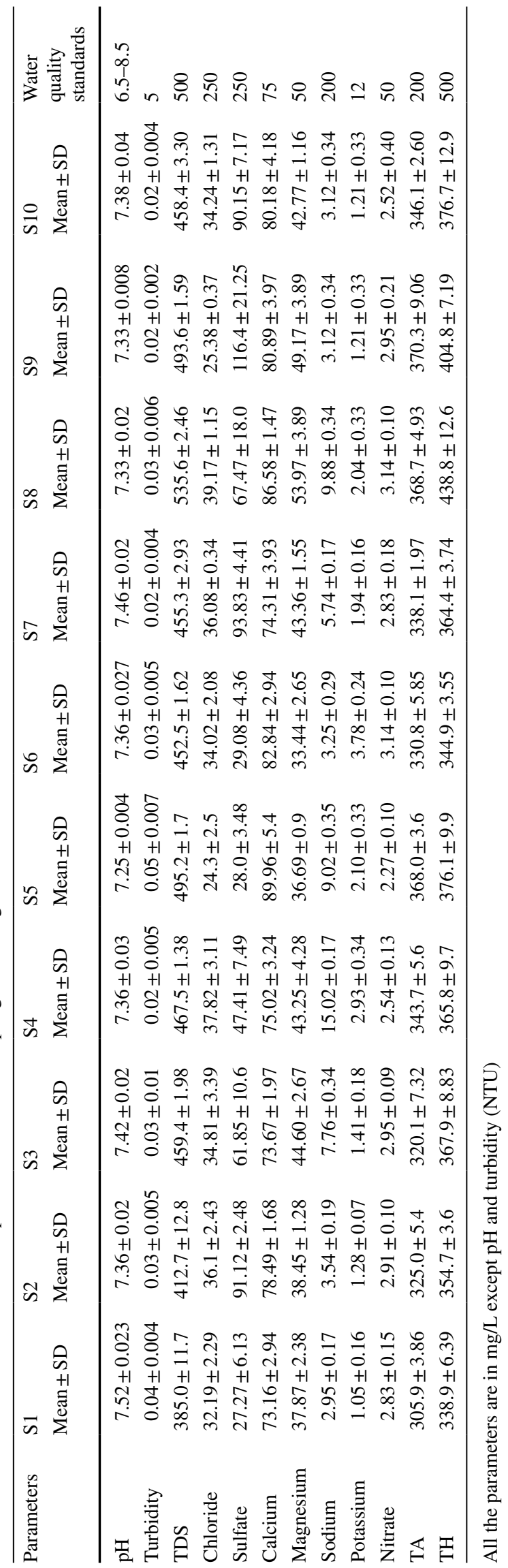




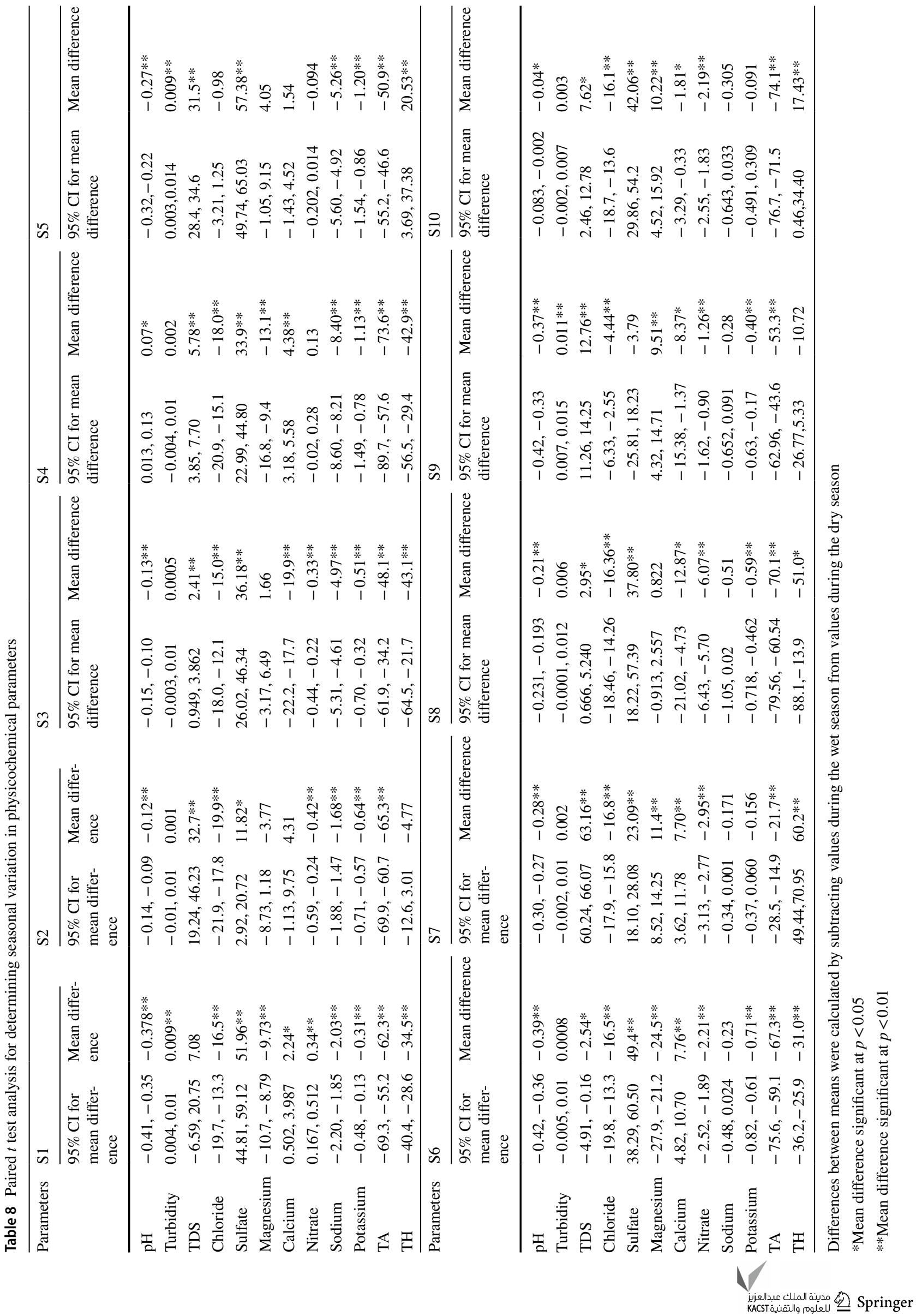


in physicochemical parameters (at 95\% probability levels) are given in Table 8.

\section{Physicochemical parameters}

$\mathrm{pH}$ refers to the degree of acidity or alkalinity of a solution or water. $\mathrm{pH}$ is a crucial indicator that can be used for assessing water quality and degree of contamination in water bodies. The results of $\mathrm{pH}$ values in all the sampling sites in both seasons ranged from 7.52 at $\mathrm{S} 1$ to 6.5 at $\mathrm{S} 9$. On this basis, all the water samples were almost neutral to slightly alkaline. These values aligned with the findings of other researchers (Al-Jiburi and Al-Basrawi 2015; Barakat et al. 2018) who reported that the $\mathrm{pH}$ of water sources in the area are characterized by a shift toward the alkaline side of neutrality; this might be due to the geological composition of the region, which consists largely of calcium carbonate $\left(\mathrm{CaCO}_{3}\right)$ (Al-Jiburi and Al-Basrawi 2015). The $\mathrm{pH}$ values in all the study sites were within an acceptable range (6.5-8.5) for both dry and wet seasons. The $\mathrm{pH}$ values, except for site $\mathrm{S} 4$, were significantly greater during wet season than during dry season $(p<0.05)$.

Turbidity is another indicator of water quality. Turbidity measures the relative clarity of the water by the presence of organic and mineral suspended particles and color producing substances (Shigut et al. 2017). The mean turbidity readings of the samples at all sampling sites and in both seasons were in the range of 0.02 to 0.06 Nephelometric Turbidity Units (NTU). Turbidity levels are very low compared to results of other studies (Al-Jiburi and Al-Basrawi 2015; Barakat et al. 2018; Shigut et al. 2017), and the results were far below the permissible level (5NTU) suggested by Iraqi and international standards for drinking water. According to (Barakat et al. 2018), "the higher levels of turbidity caused by suspended solid particles are due to fast transport pathway connecting potentially contaminated surface water with the aquifer." The low turbidity values obtained in the present study could indicate an absence of such contamination transport pathways. Seasonally, paired $t$ test results revealed that there was no statistically significant difference $(p>0.05)$ between the dry and wet seasons in terms of turbidity in most of the water samples, with exception of site S1 and site S5.

TDS, which is a measure of the salinity of groundwater, is also frequently used as a useful parameter for evaluating the quality of water and for classifying drinking and irrigation water (Barakat et al. 2018). TDS is usually estimated by electrical conductivity (EC) and there is a strong relationship between EC and TDS. EC refers to the direct measure of TDS (Abdulwahid 2013). According to Barakat et al. (2018), "the concentration of dissolved chemical substances and mineral contamination in water are controlled by the level of EC of the water." The TDS ranged from $385 \mathrm{mg} / \mathrm{L}$ at site $\mathrm{S} 1$ during the wet season to $538.6 \mathrm{mg} / \mathrm{L}$ at site $\mathrm{S} 8$ during the dry season. During the dry season, the TDS at sites S5, S7, S8, and S9 exceeded the maximum contaminant level $(500 \mathrm{mg} / \mathrm{L})$ based on the EPA standards (EPA 2018), while during the wet season, only site S8 exceeded the EPA maximum contaminant level. A similar result was obtained by Abdulwahid (2013) and Idoko and Oklo (2012). These higher TDS values could be due to the natural weathering of certain sedimentary rocks or a certain anthropogenic source, e.g., irrigation discharge, domestic effluents, and sewage effluent. The TDS values in most sampled sites were significantly higher in the wet season $(p<0.05)$ compared to the dry season, except at sites S5 and S10.

Chloride is one of the important water quality indicators and is widely found in nature in the form of salts of sodium $(\mathrm{NaCl})$, potassium $(\mathrm{KCl})$, and calcium $\left(\mathrm{CaCl}_{2}\right)$. There are numerous natural and anthropogenic factors that contribute to chloride levels in groundwater, including geological weathering, leaching from rocks, domestic effluent, irrigation discharge, agricultural use, etc. (Barakat et al. 2018). In the present investigation, the values of $\mathrm{Cl}^{-}$ranged from 15.71 to $23.3 \mathrm{mg} / \mathrm{L}$ during the dry season and 24.32 to $39.17 \mathrm{mg} / \mathrm{L}$ during the wet season. These variations could be due to the variations in geology, rainfall, dissolution of fluid inclusions, $\mathrm{Cl}^{-}$bearing minerals at these sites, or the existence of potentially polluted sources, such as domestic effluent, fertilizers, and septic tank effluent. The results revealed that chloride values in water samples during wet and dry seasons were all within the permissible limit $(250 \mathrm{mg} / \mathrm{L})$ for drinking water according to the EPA standards (EPA 2018). Chloride values in all spring water samples were found to be significantly greater during wet season than during dry season $(p<0.05)$. A possible explanation of the higher levels of $\mathrm{Cl}^{-}$during the rainy season is that the $\mathrm{Cl}^{-}$ion may be carried by rainwater into the groundwater.

Sulfate $\left(\mathrm{SO}_{4}{ }^{2-}\right)$ is another important chemical parameter for water quality and has an influence on the taste and odor of drinking water (Bouslah et al. 2017). Water containing higher levels of $\mathrm{SO}_{4}{ }^{2-}$ could have a noticeable taste and might cause a laxative effect in unaccustomed consumers (WHO 2017). $\mathrm{SO}_{4}{ }^{2-}$ in the aquifer system is derived primarily from weathering of two major forms of $\mathrm{SO}_{4}{ }^{2-}$ containing rocks, namely pyrite and gypsum, in addition to the inputs from anthropogenic activities (Ziani et al. 2017). $\mathrm{SO}_{4}{ }^{2-}$ values of the sampled spring water for dry and wet seasons ranged from 79.24 to $116.9 \mathrm{mg} / \mathrm{L}$ and 27.27 to $116.4 \mathrm{mg} / \mathrm{L}$, respectively. The lowest values of $\mathrm{SO}_{4}{ }^{2-}$ were observed at the same site ( $\mathrm{S} 1)$ during both seasons. $\mathrm{SO}_{4}{ }^{2-}$ values were relatively high but within the permissible limit $(250 \mathrm{mg} / \mathrm{L})$ recommended by the EPA for drinking water (EPA 2018). The results align with the results of previous studies in the Kurdistan region. Abdulwahid (2013) and Ahmad (2014) note that Kurdistan region inland waters generally contain 
a significant amount of $\mathrm{SO}_{4}^{2}$. This is due to the presence of gypsum-rich sedimentary rock and a shallow aquifer, which result in much higher sulfate values than other in other parts of the world (Abdulwahid 2013). On the other hand, it was found the $\mathrm{SO}_{4}{ }^{2-}$ values at all most all water sampling sites were significantly higher $(p<0.05)$ during the dry season than the wet season. The lower concentration of $\mathrm{SO}_{4}{ }^{2-}$ in the wet season may reflect the dilution of groundwater by rainwater.

Calcium and magnesium are also important parameters for assessing water quality because of their direct relationship with the development of water hardness. The concentrations of these two elements in natural water depend upon the type of rocks. They are both essential to human health in limited amounts. In the current study, the values of $\mathrm{Ca}^{2+}$ ranged from 40.97 to $90.4 \mathrm{mg} / \mathrm{L}$ during the dry season and 73.16 to $89.96 \mathrm{mg} / \mathrm{L}$ during the wet season. Except for sites S3, S5, and S6, the values of $\mathrm{Ca}^{2+}$ at all the studied sites were greater than the permissible limit $(75 \mathrm{mg} / \mathrm{L})$ as per Iraqi standards (Drinking Water Standard IQS:417 2001). On the other hand, the $\mathrm{Mg}^{2+}$ values ranged from 28.14 to $51.06 \mathrm{mg} / \mathrm{L}$ during the dry season and 33.44 to $53.97 \mathrm{mg} / \mathrm{L}$ during the wet season. The results revealed that, except at site $\mathrm{S} 7$ during the dry season and site 8 during the wet season, the values of $\mathrm{Mg}^{2+}$ at all sampling sites did not exceed the permissible limit of $50 \mathrm{mg} / \mathrm{L}$ as per Iraqi standards (Drinking Water Standard IQS:417 2001). This variation in $\mathrm{Ca}^{2+}$ and $\mathrm{Mg}^{2+}$ levels might be related to the weathering of rocks and mineral content of each ion, such as sedimentary rocks, limestone, dolomite, gypsum, aragonite, the mineral of igneous rock, feldspars amphibole and pyroxene, and the $\mathrm{pH}$ value of each source (Hem 1985). Therefore, a simple physical treatment of the study spring water is preferable to minimize loads of these nutrients. In the present investigation, in general, it was also observed that the level of $\mathrm{Ca}^{2+}$ exceeded the level of $\mathrm{Mg}^{2+}$; this case could be attributed to the chemical properties of the soil and geological origin of water source (Toma et al. 2013). Except for sites S3 and S6, all sites had significantly a higher value of $\mathrm{Ca}^{2+}$ during the dry season than in the wet season, while half of the sampling sites showed significantly higher values of $\mathrm{Mg}^{2+}$ during the wet season $(p<0.05)$ than the dry season. The higher values of $\mathrm{Ca}^{2+}$ in the dry season may be due to the rapid ingress of rainwater, which reduces the dissolution of soil minerals and rocks (Al-Khashman 2008).

Sodium $\left(\mathrm{Na}^{+}\right)$and potassium $\left(\mathrm{K}^{+}\right)$are also widely used as important indicators for assessing water quality. Sodium is an essential nutrient needed by the human body for a number of functions such as muscle and nerve function, but an elevated concentration of $\mathrm{Na}^{+}$may cause a high chance of blood pressure and consequently increase the rate kidney failure (Batool et al. 2018). On the other hand, although no adverse health effects have been reported to be caused by potassium intake through drinking water, it can cause an unpleasant taste and corrosion of pipes (Karavoltsos et al. 2008). Sodium in the aquifer system is mainly derived from the dissolution of salt minerals and silicate weathering (Ziani et al. 2017). In the present study, the values of $\mathrm{Na}^{+}$ ranged from 0.93 to $6.62 \mathrm{mg} / \mathrm{L}$ during the dry season and 2.95 to $15.02 \mathrm{mg} / \mathrm{L}$ during the wet season. It was noticed that the minimum and maximum values of $\mathrm{Na}^{+}$have been recorded for both the dry and the wet seasons at the same sites ( $\mathrm{S} 1$ and $\mathrm{S} 4$ ). The differences in $\mathrm{Na}^{+}$values could be related to the geological variation or rock mineral composition of these sites. On the other hand, $\mathrm{K}^{+}$values ranged from 0.64 to $3.55 \mathrm{mg} / \mathrm{L}$ during the dry season and 1.05 to $3.78 \mathrm{mg} / \mathrm{L}$ during the wet season. The minimum and maximum values of $\mathrm{K}^{+}$were also recorded for both dry and wet seasons at the same sites (S1 and S6). Again, this could be related to the geological variation or rock mineral composition at these sites. The $\mathrm{Na}^{+}$and $\mathrm{K}^{+}$concentrations from the study sites were lower than the permissible limits during both dry and wet seasons. In almost all water samples, the concentrations of $\mathrm{K}^{+}$were slightly lower than $\mathrm{Na}^{+}$. The $\mathrm{K}^{+}$ is fixed by clay minerals and participates in the formation of secondary minerals, which could explain the low $\mathrm{K}^{+}$levels (Scheytt 1997). Concerning the seasonal variation, it was found that $\mathrm{Na}^{+}$values at almost all sites and $\mathrm{K}^{+}$at five sites were significantly higher $(p<0.05)$ during the wet season than the dry season.

Nitrate $\left(\mathrm{NO}_{3}{ }^{-}\right)$is another important parameter for assessing water quality. Nitrate is considered undesirable in drinking water as it can cause a number of health disorders, such as methemoglobinemia in infants, gastric cancer, goiter, birth malformations, and hypertension (Majumdar and Gupta 2000; Shigut et al. 2017). Natural concentrations of $\mathrm{NO}_{3}{ }^{-}$in groundwater are generally low, but concentrations increase as a result of anthropogenic activities, such as agricultural activities, and discharge of domestic effluent and septic tank effluent (Barakat et al. 2018). The $\mathrm{NO}_{3}{ }^{-}$concentrations in analyzed samples ranged from 2.18 to $3.17 \mathrm{mg} / \mathrm{L}$ during the dry season and 2.27 to $3.14 \mathrm{mg} / \mathrm{L}$ during the wet season. The $\mathrm{NO}_{3}{ }^{-}$values of all the spring water samples were far below the prescribed limit $(50 \mathrm{mg} / \mathrm{L})$ as per WHO standards (WHO 2017). Except for site S1, the $\mathrm{NO}_{3}{ }^{-}$concentration during the wet season was significantly higher $(p<0.05)$ than during the dry season. This data agreed with results of other researchers (Vilane and Dlamini 2016) who stated that "this difference in the means may be attributed to runoff driven nitrates from the surrounding areas, which accumulated during the dry period and deposited in the spring during the wet season."

Total alkalinity (TA) refers to the capability of water to resist changes in $\mathrm{pH}$. Carbonate and bicarbonate alkali substances represent the major forms of alkalinity in natural waters. Alkalinity testing is highly important for evaluating 
water alkalinity changes due to anthropogenic disturbances (Barakat et al. 2018). The TA in the study area was mainly attributed to bicarbonate alkalinity, as reported by Abdulwahid (2013). TA values for the spring water samples in the study region ranged from 243.6 to $317 \mathrm{mg} / \mathrm{L}$ during the dry season and 305.9 to $370 \mathrm{mg} / \mathrm{L}$ during the wet season. Seasonal variation analyses revealed that virtually all sites have significantly higher values of TA during the wet season $(p<0.05)$ than during the dry season. The minimum and maximum values recorded for both dry and wet seasons occurred at the same sites (S1 and S9). According to Iraqi standards (Drinking Water Standard IQS:417 2001), the TA values of all spring water samples exceeded the permissible limit of $200 \mathrm{mg} / \mathrm{L}$.

The total hardness (TH) is another essential indicator for assessing water quality for domestic, industrial, or agricultural purposes (Al-Jiburi and Al-Basrawi 2015). The development of hardness in water is primarily derived from dissolved alkaline earth metals, such as calcium and magnesium, with all other divalent cations also contributing to the concentration (Barakat et al. 2018). The rocks surrounding the water body are largely the source of $\mathrm{TH}$, although some anthropogenic activity could contribute to varying concentrations (Bouslah et al. 2017). The TH values ranged from 304.4 to $424.6 \mathrm{mg} / \mathrm{L}$ during the dry season and 338.9 to $438.8 \mathrm{mg} / \mathrm{L}$ during the wet season, and the minimum and maximum values of $\mathrm{TH}$ were recorded at the same sites (S1 and S8). The TH values of all the water spring samples in the present study were below the permissible limit $(500 \mathrm{mg} / \mathrm{L})$ as per Iraqi standards (Drinking Water Standard IQS:417 2001), although the values were close to the allowable level. Higher values for $\mathrm{TH}$ were found in the work conducted by other researchers (Abdulwahid 2013; Barakat et al. 2018; Vilane and Dlamini 2016). Since the TH depends mainly on the geological context, the high values observed could be related to the lithological nature of the aquifer formation which corresponds to Jurassic carbonate rocks of the mountains in the study area. At these TH levels, there could be adverse effects on human health in the long-term (Barakat et al. 2018). Therefore, a simple physical treatment of the study spring water is preferable to minimize hardness. There is significant seasonal variation in the TH values, and almost all of the sites showed significantly higher TH values during wet season than during dry season, except at sites S5, S7, and S10. This could be attributed to the solvent action of rainwater coming into contact with soil and rocks capable of dissolving calcium and magnesium and that promote water hardness (Vilane and Dlamini 2016).

\section{Overall water quality indices}

For evaluating the WQI of the sampled spring water, the weighted arithmetic index method (Brown et al. 1972) was used based on the measured values of the physicochemical parameters. The WQI is the most effective way to communicate water quality because it presents the overall water quality results, rather than the results for each separate parameter (Toma et al. 2013). The WQI values for all spring water samples for each season are presented in Table 9. In the present study, the WQI was calculated twice for each season, once for all parameters and once for specified parameters. Where parameters were close to or exceeded the maximum permissible limits, such as TDS, $\mathrm{Ca}^{2+}, \mathrm{Mg}^{2+}, \mathrm{K}^{+}, \mathrm{SO}_{4}{ }^{2-}$, $\mathrm{TA}$, and $\mathrm{TH}$, these parameters showed the maximum influence on the WQI.

The minimum and maximum values of WQI based on all parameters ranged from 10.76 to 18.13 during the dry season and 17.10 to 20.45 during the wet season, and these values indicate "excellent" class for drinking purposes. When applying WQI based on specified parameters, the WQI score

Table 9 WQI and classification for the sampled sites

\begin{tabular}{|c|c|c|c|c|c|c|c|c|c|}
\hline \multirow[t]{3}{*}{ Sites codes } & \multirow[t]{3}{*}{ Site name } & \multicolumn{4}{|c|}{ Dry season } & \multicolumn{4}{|c|}{ Wet season } \\
\hline & & \multicolumn{2}{|c|}{ All parameters } & \multicolumn{2}{|c|}{ Specified parameters } & \multicolumn{2}{|c|}{ All parameters } & \multicolumn{2}{|c|}{ Specified parameters } \\
\hline & & WQI & Water quality & WQI & Water quality & WQI & Water quality & WQI & Water quality \\
\hline S1 & Kyle Baze & 11.44 & Excellent & 30.81 & Good & 19.0 & Excellent & 35.8 & Good \\
\hline $\mathrm{S} 2$ & Kani Mazne & 13.79 & Excellent & 35.7 & Good & 17.25 & Excellent & 39.24 & Good \\
\hline S3 & Miska & 15.11 & Excellent & 35.33 & Good & 18.71 & Excellent & 40.9 & Good \\
\hline $\mathrm{S} 4$ & Xshxasha & 18.13 & Excellent & 38.45 & Good & 19.88 & Excellent & 49.1 & Good \\
\hline S5 & Beqolke & 11.17 & Excellent & 39.95 & Good & 17.10 & Excellent & 44.98 & Good \\
\hline S6 & Bnavi & 13.13 & Excellent & 48.12 & Good & 20.45 & Excellent & 51.11 & Poor \\
\hline S7 & Kani Mase & 16.46 & Excellent & 34.21 & Good & 20.15 & Excellent & 44.16 & Good \\
\hline S8 & Derishke & 14.25 & Excellent & 42.72 & Good & 19.85 & Excellent & 50.39 & Poor \\
\hline S9 & Maye & 10.76 & Excellent & 40.24 & Good & 18.04 & Excellent & 44.1 & Good \\
\hline $\mathrm{S} 10$ & Bedhi & 16.18 & Excellent & 39.38 & Good & 17.94 & Excellent & 41.0 & Good \\
\hline
\end{tabular}


ranged from 30.81 to 48.12 for the dry season and 35.8 to 51.11 for wet season, and these values indicate "good" quality for drinking purposes, except at sites S6 and S8 during the wet season, which were classified as "poor" water quality and unsuitable for drinking purposes. The unsuitability of these two spring water samples could be due to the contact of rainwater with the sedimentary rock in the region leading to dissolution of ions into the aquifer or could be due to various anthropogenic activities, such as sewage disposal, waste disposal, agricultural activities, the presence of dirty drainage behind the spring water source, and anthropogenic pollution from the nearby dumpsite. However, these two sites with poor water quality could be suitable for drinking water purposes following a simple purification treatment, such as filtration.

\section{Conclusion}

The current study has been conducted to evaluate the quality of spring water based on several physicochemical parameters. Based on individual parameters, the majority of water samples were found to be suitable for drinking purposes and within permissible limits according to the chosen standard, except for a few samples, where TDS, TH, $\mathrm{Ca}^{2+}, \mathrm{Mg}^{2+}$, and $\mathrm{TH}$ were close to or exceeded the permissible limits of Iraqi standards, which indicates the water is not suitable for drinking without further treatment.

The overall WQI revealed that, by including all physicochemical parameters, all spring water samples were classified as "excellent" quality during both wet and dry seasons. When using parameters which have values close or exceeding the maximum acceptable limits, the water quality status was "good" quality for all water samples, except at two sites (S6 and S8), during the wet season which were classified as "poor" quality.

Based on the results of the present study, the current physicochemical parameters concentrations have no noticeable negative impacts on human health but could have negative impacts on human health in the long term, particularly where sites have higher values for some of the investigated parameters. Therefore, it is recommended that a simple physical treatment such as filtration of the study spring water is desirable to reduce nutrient loads and to ensure a betterquality water supply for the rural people. Furthermore, it is mandatory to regularly monitor these water sources in order to detect any changes in water quality parameters.

Acknowledgements I would like to express my sincere appreciation to the research center at the College of Agriculture, University of Duhok, for access to the laboratory equipment. I am also grateful to the College of Agriculture, University of Duhok, for providing me with the financial and technical support to carry out this project.
Open Access This article is distributed under the terms of the Creative Commons Attribution 4.0 International License (http://creativeco mmons.org/licenses/by/4.0/), which permits unrestricted use, distribution, and reproduction in any medium, provided you give appropriate credit to the original author(s) and the source, provide a link to the Creative Commons license, and indicate if changes were made.

\section{References}

Abbasi T, Abbasi SA (2012) Water quality indices. Elsevier, Amsterdam

Abdulwahid S (2013) Water quality index of delizhiyan springs and Shawrawa river within Soran district, Erbil, Kurdistan region of Iraq. J Appl Environ Biol Sci 3:40-48

Ahmad AB (2014) Evaluation of groundwater quality index for drinking purpose from some villages around Darbandikhan district, Kurdistan Region-Iraq. IOSR J Agric Vet Sci 7:34-41

Al-Jiburi HK, Al-Basrawi NH (2013) Hydrogeological map of Iraq, scale 1: 1000 000, 2013. Iraqi Bull Geol Min 11:17-26

Al-Khashman OA (2008) Assessment of the spring water quality in The Shoubak area, Jordan. The Environmentalist 28:203-215

Alobaidy AHMJ, Abid HS, Maulood BK (2010) Application of water quality index for assessment of Dokan lake ecosystem, Kurdistan region, Iraq. J Water Resour Prot 2:792-798

APHA (1995) WPCF, Standard methods for the examination of water and wastewater. American Public Health Association, Washington, DC

Barakat A, Meddah R, Afdali M, Touhami F (2018) Physicochemical and microbial assessment of spring water quality for drinking supply in Piedmont of Béni-Mellal Atlas (Morocco). Phys Chem Earth Parts A/B/C 104:39-46

Batool A, Samad N, Kazmi SS, Ghufran MA, Imad S, Shafqat M, Mahmood T (2018) Spring water quality and human health: an assessment of natural springs of margalla hills Islamabad zone-III. Int J Hydrol 2:41-46. https://doi.org/10.15406/ ijh.2018.02.00049

Bora M, Goswami DC (2017) Water quality assessment in terms of water quality index (WQI): case study of the Kolong River, Assam, India. Appl Water Sci 7:3125-3135

Bouslah S, Djemili L, Houichi L (2017) Water quality index assessment of Koudiat Medouar Reservoir, northeast Algeria using weighted arithmetic index method. J Water Land Dev 35:221-228

Brown RM, McClelland NI, Deininger RA, Tozer RG (1970) A water quality index - do we dare. Water Sew Works 117:339-343

Brown R, Mccleiland N, Deiniger R, Oconnor M (1972) Water quality index-crossing the physical barrier. In: Proceedings of international conference on water pollution research, Jerusalem, pp 787-797

Drinking Water Standard IQS:417 (2001) Central Organization for Quality Control and Standardization, Council of Ministers, Republic of Iraq

EPA (2018) Edition of the drinking water standards and health advisories. EPA, Washington, DC

Etim E, Odoh R, Itodo A, Umoh S, Lawal U (2013) Water quality index for the assessment of water quality from different sources in the Niger Delta Region of Nigeria. Front Sci 3:89-95

Faniran J, Ngceba F, Bhat R, Oche C (2001) An assessment of the water quality of the Isinuka springs in the Transkei region of the Eastern Cape, Republic of South Africa. Water SA 27:241-250

Ganiyu S, Olurin O, Ojo A, Badmus B, Jegede O (2017) Quality assessment of spring and well waters: an approach using water quality index and multivariate statistical analysis. Afr Rev Phys $12: 47-64$ 
Gazete R (1997) Ic-ilebilir nitelikteki suların istihsali, ambalajlanması, satıs-1 ve denetlenmesi hakkında yonetmelik Resmi Gazete no 23144, 18101997 (in Turkish)

Hem JD (1985) Study and interpretation of the chemical characteristics of natural water, vol 2254. Department of the Interior, US Geological Survey, Reston

Horton RK (1965) An index number system for rating water quality. J Water Pollut Control Fed 37:300-306

Idoko M, Oklo A (2012) Seasonal variation in physico-chemical characteristics of rural groundwater of Benue State, Nigeria. J Asian Sci Res 2:574-586

IPCC (2007) Climate change 2007: impacts, adaptation and vulnerability. Contribution of working group II to the fourth assessment report of the intergovernmental panel on climate change. Cambridge University Press, Cambridge, UK

Karavoltsos S, Sakellari A, Mihopoulos N, Dassenakis M, Scoullos MJ (2008) Evaluation of the quality of drinking water in regions of Greece. Desalination 224:317-329

Kaviarasan M, Geetha P, Soman K (2016) GIS-based ground water quality monitoring in Thiruvannamalai District, Tamil Nadu, India. In: Suresh L, Panigrahi B (eds) Proceedings of the international conference on soft computing systems. Advances in intelligent systems and computing, vol 397. Springer, Dordrecht, pp 685-700

Majumdar D, Gupta N (2000) Nitrate pollution of groundwater and associated human health disorders. Indian J Environ Health 42:28-39

Mishra AK, Singh VP (2010) A review of drought concepts. J Hydrol 391:202-216

Motsara M, Roy RN (2008) Guide to laboratory establishment for plant nutrient analysis, vol 19. Food and Agriculture Organization of the United Nations, Rome

Poudel DD, Duex TW (2017) Vanishing springs in Nepalese mountains: assessment of water sources, farmers' perceptions, and climate change adaptation. Mt Res Devel 37:35-46

Reza R, Singh G (2010) Heavy metal contamination and its indexing approach for river water. Int J Environ Sci Technol 7:785-792

Samantray P, Mishra BK, Panda CR, Rout SP (2009) Assessment of water quality index in Mahanadi and Atharabanki Rivers and Taldanda Canal in Paradip area, India. J Hum Ecol 26:153-161
Scheytt T (1997) Seasonal variations in groundwater chemistry near Lake Belau, Schleswig-Holstein, Northern Germany. Hydrogeol J 5:86-95

Shigut DA, Liknew G, Irge DD, Ahmad T (2017) Assessment of physico-chemical quality of borehole and spring water sources supplied to Robe Town, Oromia region, Ethiopia. Appl Water Sci 7:155-164

Singh AK, Hasnain S (1999) Environmental geochemistry of Damodar River basin, east coast of India. Environ Geol 37:124-136

Tallaksen LM, Van Lanen HA (2004) Hydrological drought: processes and estimation methods for streamflow and groundwater, vol 48. Elsevier, Amsterdam

Toma J, Ahmed R, Abdulla Z (2013) Application of water quality index for assessment water quality in some bottled water Erbil City, Kurdistan Region, Iraq. J Adv Lab Res Biol 4:118-124

Tyagi S, Sharma B, Singh P, Dobhal R (2013) Water quality assessment in terms of water quality index. Am J Water Resour 1:34-38

Van der Merwe CR (1962) Soil groups and subgroups of South Africa. Stellenbosch University, Stellenbosch

Vilane BRT, Dlamini J (2016) An assessment of the Mhlambanyoni spring water quality at Sigombeni, Swaziland. J Agric Sci Eng 2:40-45

WHO (2017) Guidelines for drinking-water quality: first addendum to the fourth edition. WHO, Geneva

Yisa J, Jimoh TO, Oyibo OM (2012) Underground water assessment using water quality index. Leonardo J Sci 21:33-42

Yogendra K, Puttaiah E (2008) Determination of water quality index and suitability of an urban waterbody in Shimoga Town, Karnataka. In: Proceedings of Taal2007: the 12th world lake conference, pp 342-346

Ziani D, Abderrahmane B, Boumazbeur A, Benaabidate L (2017) Water quality assessment for drinking and irrigation using major ions chemistry in the Semiarid Region: case of Djacer Spring, Algeria. Asian J Earth Sci 10:9-21

Publisher's Note Springer Nature remains neutral with regard to jurisdictional claims in published maps and institutional affiliations. 